\title{
1. 時間治療-総論：生体の時計システムと時間治療
}

岡 村 均*

\section{1.はじめに}

生体リズムは地球に住む生物にとっては基本的性質 であり，哺乳類においては，多くの生理機能が生体時 計の下に動いている．薬学の分野においても，投薬時 刻を考慮して効果的な薬物治療を実践する時間薬理学 が従来より発展してきた。多くの治療薬で治療効果や 有害反応は投薬時刻で異なる。治療効果や有害反応が 投薬時刻で変化する要因として, 薬物の体内動態が投 薬時刻で異なる薬物動態学的要因と, 薬物に対する反 応や感受性, 受容体の発現量が時刻で異なる薬力学的 要因とがある。前世紀末に生体リズムを発振する時計 遺伝子 clock genes が単離され, 全身の細胞に存在し て，細胞の代謝を司っていることがわかった。このわ ずか数個の時計遺伝子は数千もの細胞機能に重要な遺 伝子を周期的に発現させる。現在，この時計遺伝子が どのように, 疾患とかかわり, また薬物の動態に関与 しているのかの研究が進行しつつある. 本稿において は，新しい生体時計の考え方，それを基にした疾病の 理解と新しい時間治療について概観する.

\section{2. 生体時計研究は時代の要求}

近年, 交代性勤務や長時間労働の一般化や, 不夜城 と化した人工的な生活環境変化の急速な浸透により， 生体リズムシステムは破綻の危機に陥っている. 生体 リズムの異常は, 従来の睡眠異常や躁うつ病のみでな く, 現在では, 高血圧, メタボリック症候群, 発癌な ど生活習慣病に至ることが臨床疫学で明らにされてい る.この疫学的事実を分子レベルで明らかにする研究 が時計遺伝子を中心として今世紀になり始まった.

\section{3. 新しい生体時計の考え方}

時計遺伝子は 20 世紀末に発見され，その発見によ り生体リズムはまったく新しい概念で説明されるよう

* 京都大学大学院薬学研究科医薬創成情報科学専攻システ ムバイオロジー分野

于 606-8501＼cjkstart京都市左京区吉田下阿達町 46-29
になった，それによると，時間は全身に存在する数十 兆の細胞時計で発信されることが明らかになった，細 胞時計の中心で時を刻んでいるのはPer 遺伝子群 (Per1, Per2, Per3) で, 強い転写リズムを起こす1). このリズミックな転写は, 促進因子である CLOCK と BMAL1 が二量体を形成し，プロモーター上の E-box に結合し, P er 遺伝子群の転写を促進し, 産生された mRNA から PER 蛋白質群ができ，これが核の中へ 入って転写抑制因子である CRY 蛋白質群 (CRY1, CRY2）と結合して, 転写促進因子を抑制し, フィード バックループが閉じて転写が減少する.

このような数十兆個もの末梢（細胞）時計はばらば らに時をうつのであろうか. 生体は全体として調和の とれた時を発現するのであり，その統合機構は脳にあ る。脳の視床下部にある小さな神経核である視交叉上 核がその場所である。視交叉上核は数千個の細胞から なる時間発振に特化した神経核でありほぼ恒久的に自 発的にリズムを発振することができ，ここからのシグ ナルは, 交感神経系, 副交感神経系, グルココルチコ イドに変換され，全身の末梢時計を統括している.

リズム発振とともに，生体リズムにとっての重要な 事項に，振動子自身の外界リズム周期とのリズム位相 の同調があるが，外界の光シグナルは，中枢時計の Per1 遺伝子上の cis-element の $\mathrm{Ca}^{2+} / \mathrm{cAMP}$ response element（CRE）を介し時計遺伝子の発現を変化させ て，明暗シグナルを同調させることがわかっている.

\section{4. 明るい夜が引き起こすリズムの変動}

ところが, この正確無比な時計が今, 挑戦を受けて いる，今や明暗を自由に操る手段を得た人類は，「明 るい」夜を手に入れた。明るい夜は，これまで人々が 暮らしていた昼夜のサイクルを完全に破壊し，この人 口環境の世界では，これまで環境の変動に対応してい た我々の生体時計は時代遅れのものとも言えるまでに なった．個人的な趣味で「夜」寝ずに過ごす人が増え ると, その需要に応じた多くのコンビニエンスストア 
など夜開いている店ができ, 寂しい夜をなごませるこ れらの店では，数千ルクスのこうこうと照らされた昼 間と見まがうばかりの照明で満たされる，夜間の光照 射は人体にどのような変化を与えるのか？ 照射する 光は, 網膜の光受容細胞を興奮させ, 網膜の神経節細 胞の発火を促し，その神経末端から視交叉上核の生体 時計を司る一群の細胞に向けて，神経伝達物質である グルタミン酸が放出される。これにより体内時計の時 計遺伝子が誘導され，体内時計が後ろに動く 2 . だか ら，朝起きにくくなる．このように，夜の光照射は時 計遺伝子の発現を人為的に変化させることができるの である．また，光を昼夜問わず照射し続けると，中枢 時計の発振機構が減弱することが知られている.

\section{5 . リズムと疾病}

最近の, 時計遺伝子の研究の進展により, 従来から 知られていた, 睡眠・覚醒やホルモン分泌だけでなく, 脂質代謝, 細胞分裂や骨形成の 24 時間リズムを司っ ている遺伝子が時計遺伝子によってコントロールされ ていることがわかってきた. DNA マイクロアレイの 研究では, 哺乳類の細胞に発現する全遺伝子のうち, 驚くべきことにおよそ5〜10\%にあたる数千の遺伝子 が分子時計の制御を受けてリズミックに発現している ことが分かったのである.

この時計遺伝子の細胞内機能としては, まず, 細胞 周期のタイミングが制御されていることが明らかと なった ${ }^{3)}$. 肝蔵の細胞周期は, 朝になると抑制性のキ ナーゼである wee1 の発現が下がり, 細胞は G2 期か ら $\mathrm{M}$ 期に突入するのである。この研究と, Per2ノッ クアウトマウスにおける $c-m y c$ の発現増加を伴う易 発癌性の報告は, 時計遺伝子の発振機構不全に起因す る細胞増殖不全が発癌に関与することを示した研究と して大きな注目を集めている。 エネルギー代謝とのか かわりでは, Clockミュータントマウスがメタボリッ ク症候群を示すこと，また膵臓のランゲルハンス氏島 の時計を欠失させるとインスリン分泌不全を伴う糖尿 病が報告されているが，その分子機構はいまだ明らか ではない．生体リズムは多くの生活習慣病に関与する と考えられる ${ }^{4)}$.

\section{6. リズムと高血圧}

従来より心筋梗塞や脳血管障害などと密接な関係が ある高血圧の病態が日周変動を来たすことはよく知ら
れていたが, その明確な分子機構は全く不明であった。 最近我々は，この時計遺伝子であるCry1 とCry2 を 失った遺伝子改変マウス（以降 $C r y$-null マウスと呼 ぶ）の血圧について検索したところ，Cry-null マウス は食塩感受性の高血圧を示すことを見いだしだ)。血 中アルドステロン值を測定すると，野生型より 5 10 倍もの濃度を示し, 原発性アルドステロン症の病態を 示すことを明らかにした. DNA マイクロアレイ解析 を用いて副腎機能障害の原因分子を探ったところ，副 腎の球状層に特異的に発現する新しい夕イプの $3 \beta$ 水 酸化ステロイド脱水素酵素 (3 $\beta$-HSD) が Cry-null マウ スにおけるアルドステロンの異常産生に関与すること が分かった，ヒトにおいても，副腎球状層特異的 $3 \beta$ HSD サブタイプが存在しており，この生体時計に制 御される新酵素が食塩感受性高血圧にどの程度関与し ているのかが注目される。この新規酵素は, ヒトの副 腎の検索結果, 副腎球状層でも特異的に存在しており, ヒトの高血圧の新しい病因としての可能性がある.

\section{7.リズムと時間治療}

時間薬理学をべースとした時間治療は, 古くから発 達して，大きな成果を残している，現在，急速に，薬 物代謝に関与する酵素の時間発現や, 時計遺伝子によ る制御機構の解明が進展している．グローバリズムの 席巻する現代，生体リズム異常は，多くの生活習慣病 の発症・進展に関与する。生体リズム異常の新しい理 解による時間薬理学や時間治療学の新展開が期待され る.

\section{文献}

1) Okamura H, Doi M, Fustin JM, Yamaguchi Y, Matsuo M. Mammalian circadian clock system : molecular mechanisms for pharmaceutical and medical sciences. Adv Drug Deliv Rev. $2010 ; 62(9-10): 876-84$.

2) Asai M, Yamaguchi S, Isejima H, Jonouchi M, Moriya T, Shibata $\mathrm{S}$, et al. Visualization of $m$ Perl transcription in vitro : NMDA induces a rapid phase shift of $m$ Per 1 gene in cultured SCN. Curr Biol. 2001 ; 11(19) : 1524-7.

3) Matsuo T, Yamaguchi S, Mitsui S, Emi A, Shimoda F, Okamura H. Control mechanism of the circadian clock for timing of cell division in vivo. Science. $2003 ; 302(5643): 255-9$.

4) 岡村均. 時間と病気: 生体時計から時間医学へ（特集にあたっ て).メデイカルバイオ. $2009 ; 6$ (6) : 12-5.

5) Doi M, Takahashi Y, Komatsu R, Yamazaki F, Yamada H, Haraguchi S, et al. Salt-sensitive hypertension in circadian clockdeficient Cry-null mice involves dysregulated adrenal Hsd3b6. Nat Med. 2010 ; 16(1) : 67-74. 